\begin{tabular}{c} 
Volume and Issues Obtainable at Center for Sustainability Research and Consultancy \\
Sustainable Business and Society in Emerging Economies \\
ISSN: $2708-2172 \&(E): 2708-2504$ \\
Volume 3: Issue 4 December 2021 \\
CSRC \\
Journal homepage: $\underline{w w w . p u b l i s h i n g . g l o b a l c s r c . o r g / s b s e e}$ \\
\hline
\end{tabular}

\title{
Teaching Strategies Employed by Teachers in teaching Skills to Students of Vocational Training Institutes of Punjab Pakistan
}

Dur e Nayab, PhD Scholar, Institute of Education and Research, University of the Punjab, Lahore, Pakistan

*Ghulam Fatima, Associate Professor, Institute of Special Education, University of the Punjab, Lahore, Pakistan

Muhammad Jahanzaib, PhD Scholar, Institute of Special Education, University of the Punjab, Lahore, Pakistan

*Corresponding Author's Email: fatima.dse@pu.edu.pk

ARTICLE DETAILS

History

Revised format: Nov 2021

Available Online: Dec 2021

Keywords

Teaching strategies,

Technical and Vocational

Education and Training,

Teachers, Vocational

Training Institutes, Punjab

JEL Classification

.A20, A29

\section{OPEN ACCESS}

ABSTRACT

Purpose: The main purpose of the study was to explore the teaching strategies employed by Technical and Vocational Education and Training (TVET) teachers in Vocational Training Institutes (VTIs) established by Punjab Vocational Training Council (PVTC) Pakistan Design/Methodology/Approach: The population of the study was all 2423 teachers working in Vocational training Institutes (VTIs) of Punjab Vocational Training Council (PVTC). The sample of the study was 130 (males $=69$ and females $=61$ ) teachers which were randomly selected from VTIs of PVTC. The instrument of the study was a selfdeveloped and validated questionnaire, having the reliability of 0.87 (Cronbach Alpha). Data were collected personally and by post. Collected data were analyzed through descriptive and inferential statistics. ANOVA and Independent sample $t$-test were used to observe the differences in the responses of teachers related to their age, gender, experience, zones, professional qualification, and trainings.

Findings: The results of the study indicated that teachers were facing a lot of problems during teaching to TVET students like overcrowded classrooms, unavailability of equipment, lack of trainings and insufficient staff.

Implications/Originality/Value: The present study helps the authorities of TVET and Punjab Vocational Training Council by giving recommendations in the improvement and reformation of the current condition of TVET sector in Pakistan.

(C) 2021 The authors, under a Creative Commons AttributionNonCommercial- 4.0

Recommended citation: Nayab, D., Fatima, G. \& Jahanzaib, M. (2021). Teaching Strategies Employed by Teachers in teaching Skills to Students of Vocational Training Institutes of Punjab Pakistan. Sustainable Business and Society in Emerging Economies, 3 (4), 605-616.

\section{Introduction}

Technical and Vocational Education and Training (TVET) indicates that education and training which is 
based on providing skills, abilities and knowledge needed for a particular job (Pioneer State High School, 2020). It is the piece of tertiary education and training which gives licensed training in work related and technical skills. It covers numerous professions and industries like trades and office work, retail, accommodation, and technology that is needed by the business and labour market. Most of the courses are offered according to the interests and the needs of individuals particularly in the field of agriculture, engineering, health, the travel industry and computer application (Clayton \& Harris, 2018). Especially a large number of institutes have been running mushroom production, cultivation, cooking/baking housekeeping and many others. The main purpose is giving certain expertise and professional skills to individuals who can't acquire advanced education or are intrigued to acquire certain professional/vocational skills for their better professional carrier (Council for Technical Education and Vocational Training, 2012).

The educational policies of Pakistan also give great importance to Technical and Vocational Education and Training (TVET). Shortly after the independence, Scientific Research and Technical Education Committee for All Pakistan Educational Conference (1947) made some exceptionally great recommendations for building a sound and suitable foundation for technical and vocational education in Pakistan. The Committee proposed the establishment of a council for scientific and industrial research. The Committee recommended that this council ought to set up National Laboratories, and Technical Institutions in Pakistan (Ministry of Federal Education and Professional Training, 2018; Government of Pakistan, 1947). National Education Commission (1959) laid exceptional importance on technical and vocational education. The commission pushed on reinforcing technical and vocational education in the country to support the economy of the state.

The Education Policy (1972-1980) stressed making technical and vocational education mandatory for all students of classes VI-VIII. The National Educational Policy (1998-2010) supported the significance of technical and vocational education. The policy focused on granting the different types of skills and education to students which will assist them in their practical life if they decide to work after secondary education (Ministry of Education and Professional Training, 2018). Same as the past policies, the Education Policy (2009) has also given great importance to technical and vocational education and training. The suggestions made in this Education Policy (2009) are to incorporate and broaden technical and vocational education and training(TVET) as indicated by the needs of the area; to offer skills-based vocational training courses according to the local work market; to explain level-wise essentials for entry as an instructor in technical and vocational education and training (Government of Pakistan, 2009).

In Pakistan, numerous Government, semi-government, and Non-Government Organizations (NGOs) are providing technical and vocational education generating a semi-skilled and skilled labour force. Any individual can join Technical and Vocational Education and Training (TVET) courses through technical training centers or vocational institutes by government, non-government or private training providers (Shrestha, 2016). Technical Education and Vocational Training Authority (TEVTA) in Pakistan and Punjab Vocational Training Council (PVTC) in Punjab are playing out their roles as technical and vocational training providers on the central and provincial levels. All over the world, many developed and developing nations have been giving vocational education and technical training in many professions. Technical and Vocational Education and Training (TVET) programs cover a wide scope of professions and businesses, including skills and office work, retail, hospitality, and machines (Fatima, Bashir, Ashraf, \& Nayab, 2020).

Punjab Vocational Training Council (PVTC) was established in October 1998 by the Government of Punjab, under the Punjab Vocational Training Council Act. It was created on the public and private relationship. This council utilizes Zakat Funds for decreasing poverty and providing demand-driven skill and training to deserving and depriving youth. There are 3,634 public and private technical and vocational institutes in Pakistan, in which Punjab Vocational Training Council is running 208 vocational institutes. The number of students, who can finish their graduation from these institutes is 40,000 per 
annum. This council offers various courses related to 51 trades to needy young boys and girls.

\section{Literature Review}

According to the European Center for the Development of Vocational Training (2012), the progress of Technical and Vocational Education and Training (TVET) has become the main strategy for both developing and developed nations. Governments all over the world are at present trying to bring changes and improvements to their education and training structures, preparing frameworks to fulfill the need for a suitably skilled labour force in a developing global economy (Finnamore, 2020). Nations that need to remain in worldwide competition are facing high pressure to improve labour force quality. Vocational education is considered a significant base of social and economic development and a vital focal point of training. All developing and developed nations are focusing more on the advancement of Technical and Vocational Education and Training (TVET) to control the expanding joblessness, encouraging business (entrepreneurship), lack of money, and industrial development (Quisumbing, 2013). Despite doing all the efforts for improving TVET sector, this sector facing some of the following serious issues.

\section{Shortage of Well Trained and Qualified Teachers}

Tafida, Clement and Raihan (2015) noticed that developing nations generally experience the worst effects of the lack of qualified instructors. The issue of holding educators especially TVET instructors in educational institutions dated back to 1960s. The constant movement of instructors from teaching to better paying positions in different areas of the economy is evidently liable for the deficiency of educators of TVET. In fact, lack of TVET educators is a worldwide issue. For example, Kayode and Akanani (2016) revealed a huge deficiency of TVET instructors in the United States (US) particularly in states like Michigan, Virginia, South Dakota, Iowa and New York. As per International Labor Organization's (2010) report from some high income nations shows genuine or possible deficiencies of TVET instructors and coaches, outstandingly because of the aging of this labour force.

For instance, a report (2007) from Sweden demonstrated that the greater part of such educators were over 50 years of age. Noticeably, the issue has been compounded until very recently by challenges of rivaling frequently more worthwhile private endeavors and in quickly extending professions. Despite the new financial downturn that influenced the economy of numerous countries adversely, which might have cleared path for instructing of TVET to be more rewarding, deficiency of instructors exists in lowincome nations particularly to meet the Education for all (EFA) objectives by 2015 (UNESCO, 2010). Reasons such as low fiscal motivations and general conditions of facilities in the area of education in contrast with the industrial, business and service endeavors have been recognized as a portion of the basic components for instructors' inclination for working in industries. As Simons, Harris, Pudney and Clayton (2015) put it, one of the difficulties confronting the recruitment of TVET experts (especially for public suppliers) is the salary gap between what can be acquired as workers in industries and the pay of the educators in TVET sector. According to Kayode and Akanani (2016), deficiency of talented and skilled vocational workers is so serious to the degree that vocational and technical education as well as financial development have been influenced.

\section{Lack of Teaching and Learning Resources}

Absence of exceptional instructing and learning offices in TVET foundations is a factor that has contributed to augmenting the holes among TVET and ventures. It has been seen that most TVET establishments in Nigeria actually utilize obsolete offices that are not, at this point significant in businesses as educating and learning facilities (Shakir,2020). This is in concurrence with UNESCO (2015) that under $1 \%$ of auxiliary instruction in Nigeria is arranged towards specialized and professional abilities, more terrible still, workshops for TVET at tertiary schooling level features dumps of obsolete and old machines, hardware and devices. This unpleasant condition could be ascribed to insufficient financing of education by the government at all levels in Nigeria. As indicated by Offei-Ansah (2011), TVET educators have restricted insight of life outside classroom and no admittance to assets materials 
through which to emphasize significance. It has been seen that industries and companies are the end clients of TVET products, and as of now, skill exercises in industries are changing as the interest of the general public is changing while little or no change is occurring in TVET institutions hence there is a gap among TVET institutes and industries (Bhurtal, 2015).

\section{Objective of the Study}

The study was conducted to explore the teaching strategies adopted by teachers in teaching academics and demand-driven and employable vocational skills in various trades to needy youth enrolled in Technical and Vocational Education and Training program of 12 months duration at Vocational Training Institutes (VTIs) established by Punjab Vocational Training Council after passing matriculation.

\section{Research Question of the Study}

The study was conducted to answer the following question:

- What are the teaching strategies used by the teachers in teaching academics, ethics, life skill and demand- driven and employable vocational skills in various trades to needy young boys and girls enrolled in Vocational Education and Training Program of 12- month duration at Vocational Training Institutes (VTIs) after passing matriculation?

\section{Methodology}

The study was quantitative in nature and data were collected through questionnaires by the teachers working in Vocational Training Institutes (VTIs) of Punjab Vocational Training Council.

\section{Population}

The population of the study included 2423 TVET teachers working in 208 Vocational Training Institutes established in 36 districts of the Punjab province of Pakistan.

\section{Sample}

The sample of the study was130 TVET teachers who were randomly selected from Vocational Training Institutes of Punjab Vocational Training Council.

\section{Instrumentation}

A questionnaire was developed on teaching strategies of teachers in teaching to TVET students. It comprised of two segments: Segment I consisted of details about demographic characteristics of the teachers including their institution's name, district, gender, zone, age, educational qualification, professional qualification, attended trainings and experience. Segment II was related to their teaching practices. Five point Likert type scale from strongly disagree to strongly agree was used for all strategies. The instrument was validated by a panel of experts having expertise in research field and the reliability of the questionnaire was determined by

cronbach Alpha, which was 0.87.

\section{Data/ Analysis}

Data were analyzed by using different statistical techniques. One Way Analysis of Variance (ANOVA) and $t$-test was used to know frequency distribution of teachers' responses.

Table 1:

Frequency distribution of number of respondents on the basis of gender

\begin{tabular}{lllll}
\hline & Frequency & Percent & Valid Percent & $\begin{array}{l}\text { Cumulative } \\
\text { Percent }\end{array}$ \\
\hline Male & 69 & 53.1 & 53.1 & 53.1 \\
Female & 61 & 46.9 & 46.9 & 100.0 \\
Total & 130 & 100.0 & 100.0 & \\
\hline
\end{tabular}

Table 1 shows the gender of respondent teachers of VTIs. Majority of the respondents were male $53.1 \%$, and $46.9 \%$ were females in all four zones of Punjab. 
Table 2:

Frequency distribution of respondents on the basis of age

\begin{tabular}{lllll}
\hline & Frequency & Percent & Valid Percent & $\begin{array}{l}\text { Cumulative } \\
\text { Percent }\end{array}$ \\
\hline $20-25$ & 5 & 3.8 & 3.8 & 3.8 \\
$26-30$ & 19 & 14.6 & 14.6 & 18.5 \\
$31-35$ & 37 & 28.5 & 28.5 & 46.9 \\
$36-40$ & 21 & 16.2 & 16.2 & 63.1 \\
$41-45$ & 31 & 23.8 & 23.8 & 86.9 \\
$46-50$ & 15 & 11.5 & 11.5 & 98.5 \\
above 50 & 2 & 1.5 & 1.5 & 100.0 \\
Total & 130 & 100.0 & 100.0 & \\
\hline
\end{tabular}

Table 2 displays zone wise distribution of respondent teachers of VTIs, teaching in different districts of Punjab based on their age. It is apparent from the table that most of the teachers were in the age range of 31-35 years that is $37(28.5 \%)$.

Table 3:

Frequency distribution of teachers based on their general education

\begin{tabular}{lllll}
\hline & Frequency & Percent & Valid Percent & $\begin{array}{l}\text { Cumulative } \\
\text { Percent }\end{array}$ \\
\hline Matric & 21 & 16.2 & 16.2 & 16.2 \\
FA/FSC & 15 & 11.5 & 11.5 & 27.7 \\
BA/BSC & 57 & 43.8 & 43.8 & 71.5 \\
MA/MSC & 37 & 28.5 & 28.5 & 100.0 \\
Total & 130 & 100.0 & 100.0 & \\
\hline
\end{tabular}

Table 3, displays zone wise distribution of respondent teachers of VTIs, teaching in different districts of Punjab based on their qualification. It is apparent from the table that most of the teachers were with $\mathrm{BA} / \mathrm{BSC}$ qualification that is 57 (43.8\%), and very few were with FA/FSc, 15 (11.5\%).

\section{Table 4:}

Frequency distribution of teachers based on their professional education

\begin{tabular}{lllll}
\hline & Frequency & Percent & Valid Percent & $\begin{array}{l}\text { Cumulative } \\
\text { Percent }\end{array}$ \\
\hline AC/ refrigeration repair & 21 & & & 16.2 \\
screen printing and graphic10 & 16.2 & 16.2 & 23.8 \\
arts & & 7.7 & 7.7 & \\
diploma in electrical & 5 & 3.8 & 3.8 & 27.7 \\
diploma in plumbing & 5 & 3.8 & 3.8 & 31.5 \\
DAE mechanical & 13 & 10.0 & 10.0 & 41.5 \\
diploma in beautician & 29 & 22.3 & 22.3 & 63.8 \\
dress making & 6 & 4.6 & 4.6 & 68.5 \\
computer operator & 39 & 30.0 & 30.0 & 98.5 \\
auto mechanic & 2 & 1.5 & 1.5 & 100.0 \\
Total & 130 & 100.0 & 100.0 & \\
\hline
\end{tabular}

Table 4 shows zone wise distribution of respondent teachers of VTIs, teaching in different districts of Punjab on the basis of their professional education. It is apparent from the table that most of the teachers were computer operators by profession that is 39 (30\%). A very few were auto mechanic, $2(1.5 \%)$.

Table 5:

Frequency distribution of teachers on the basis of training courses

\begin{tabular}{lllll}
\hline & Frequency & Percent & Valid Percent & $\begin{array}{l}\text { Cumulative } \\
\text { Percent }\end{array}$ \\
\hline 1-5 workshops & 60 & 46.2 & 46.2 & 46.2 \\
6-10 workshops & 48 & 36.9 & 36.9 & 83.1 \\
11-15 workshops & 22 & 16.9 & 16.9 & 100.0 \\
Total & 130 & 100.0 & 100.0 & \\
\hline
\end{tabular}

Table 5 reflects zone wise distribution of respondent teachers of VTIs, teaching in different districts of Punjab on the basis of training courses. It is apparent from the table that most of the teachers attended 1- 
5 workshops that is 60 (46.2\%), 6-10 workshops attended by 48 (36.9\%) and very few (16.9\%) attended 11-15 workshops.

Table 6:

\begin{tabular}{lllll}
\multicolumn{5}{c}{ Frequency distribution of teachers on the basis of their teaching experience } \\
\hline & Frequency & Percent & Valid Percent & $\begin{array}{l}\text { Cumulative } \\
\text { Percent }\end{array}$ \\
\hline $1-5$ years & 34 & 26.2 & 26.2 & 26.2 \\
$6-10$ & 28 & 21.5 & 21.5 & 47.7 \\
$11-15$ & 27 & 20.8 & 20.8 & 68.5 \\
$16-20$ & 29 & 22.3 & 22.3 & 90.8 \\
$21-25$ & 12 & 9.2 & 9.2 & 100.0 \\
Total & 130 & 100.0 & 100.0 & \\
\hline
\end{tabular}

Table 6 shows zone wise distribution of respondent teachers of VTIs, teaching in different districts of Punjab on the basis of their teaching experience. It is apparent from the table that most of the teachers were with 1-5 year experience that is $34(26.2 \%)$ and very few $(9.2 \%)$ were with 21-25 year experience.

Table 7:

ANOVA for differences in mean scores in teaching strategies of teachers on the basis of their age

\begin{tabular}{llllll}
\hline & Sum of Squares & Df & Mean Square & $F$ & Sig. \\
\hline Between Groups & 2521.729 & 6 & 420.288 & 1.734 & .119 \\
Within Groups & 29819.071 & 123 & 242.431 & & \\
Total & 32340.800 & 129 & & & \\
\hline
\end{tabular}

Table 7 shows that there was no statistically significant difference among the teaching strategies of teachers of TVET institutions on the basis of their age: $F(6,123)=1.734, p=.119$. It means that teachers' teaching strategies were not different on the basis of their age in teaching different courses to students.

Table 8:

ANOVA for differences in mean scores among the teaching strategies of teachers on the basis of education

\begin{tabular}{llllll}
\hline & Sum of Squares & $D f$ & Mean Square & $F$ & Sig. \\
\hline Between Groups & 703.503 & 3 & 234.501 & .934 & .426 \\
Within Groups & 31637.297 & 126 & 251.090 & & \\
Total & 32340.800 & 129 & & & \\
\hline
\end{tabular}

Table 8 shows that there was no statistically significant difference among the teaching strategies of teachers of VTIs on the basis of their basic education: $F(6,123)=1.734, p=.426$. It means that teachers' teaching strategies were not different on the basis of their basic education in teaching different courses to students.

Table 9:

ANOVA for differences in mean scores among teaching strategies of teachers on the basis of professional qualification

\begin{tabular}{llllll}
\hline & Sum of Squares & $D f$ & Mean Square & $F$ & Sig. \\
\hline Between Groups & 7095.220 & 8 & 886.903 & 4.251 & .000 \\
Within Groups & 25245.580 & 121 & 208.641 & & \\
Total & 32340.800 & 129 & & & \\
\hline
\end{tabular}

Table 9 shows that there was statistically significant difference among the teaching strategies of teachers of VTIs on the basis of their professional education: $F(8,121)=4.251, p=.000$. It means that teachers' teaching strategies were different on the basis of their professional education in teaching different courses to students.

Table 10:

Post Hoc Comparison of teachers' teaching strategies on the basis of their professional qualification

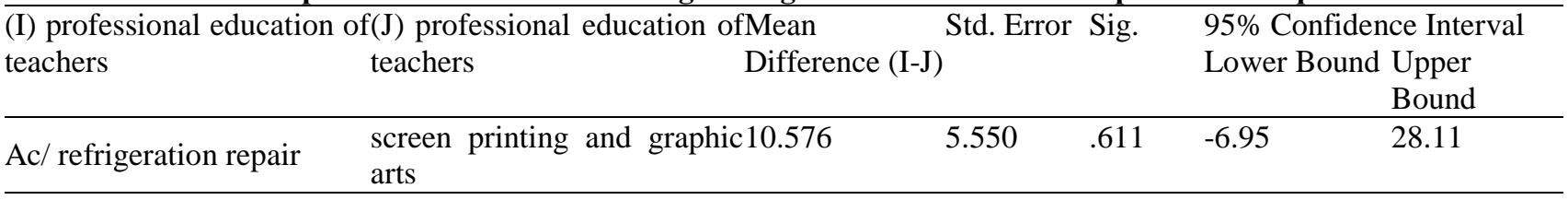




\begin{tabular}{|c|c|c|c|c|c|c|}
\hline & diploma in electrician & -19.924 & 7.188 & .135 & -42.63 & 2.78 \\
\hline & diploma in plumbing & 7.076 & 7.188 & .987 & -15.63 & 29.78 \\
\hline & DAE mechanical & 7.092 & 5.098 & .899 & -9.01 & 23.19 \\
\hline & diploma in beautician & -6.455 & 4.139 & .824 & -19.53 & 6.62 \\
\hline & dress making & 16.310 & 6.686 & .273 & -4.81 & 37.43 \\
\hline & computer operator & 2.553 & 3.910 & .999 & -9.80 & 14.90 \\
\hline & auto mechanic & 10.976 & 10.689 & .983 & -22.79 & 44.74 \\
\hline & $\mathrm{ac} /$ refrigeration repair & -10.576 & 5.550 & .611 & -28.11 & 6.95 \\
\hline & diploma in electrician & $-30.500^{*}$ & 7.912 & .006 & -55.49 & -5.51 \\
\hline & diploma in plumbing & -3.500 & 7.912 & 1.000 & -28.49 & 21.49 \\
\hline \multicolumn{2}{|c|}{ screen printing and graphicDAE mechanical } & -3.485 & 6.076 & 1.000 & -22.68 & 15.71 \\
\hline \multirow[t]{7}{*}{ arts } & diploma in beautician & $-17.031^{*}$ & 5.297 & .043 & -33.76 & -.30 \\
\hline & dress making & 5.733 & 7.459 & .997 & -17.83 & 29.29 \\
\hline & computer operator & -8.023 & 5.120 & .821 & -24.20 & 8.15 \\
\hline & auto mechanic & .400 & 11.189 & 1.000 & -34.94 & 35.74 \\
\hline & ac/ refrigeration repair & 19.924 & 7.188 & .135 & -2.78 & 42.63 \\
\hline & $\begin{array}{l}\text { screen printing and gra } \\
\text { arts }\end{array}$ & $\mathrm{c} 30.500^{*}$ & 7.912 & .006 & 5.51 & 55.49 \\
\hline & diploma in plumbing & 27.000 & 9.135 & .086 & -1.86 & 55.86 \\
\hline \multirow[t]{8}{*}{ diploma in electrician } & DAE mechanical & $27.015^{*}$ & 7.601 & .015 & 3.01 & 51.03 \\
\hline & diploma in beautician & 13.469 & 6.994 & .598 & -8.62 & 35.56 \\
\hline & dress making & $36.233^{*}$ & 8.747 & .002 & 8.61 & 63.86 \\
\hline & computer operator & $22.477^{*}$ & 6.861 & .036 & .80 & 44.15 \\
\hline & auto mechanic & 30.900 & 12.085 & .216 & -7.27 & 69.07 \\
\hline & $\mathrm{ac} /$ refrigeration repair & -7.076 & 7.188 & .987 & -29.78 & 15.63 \\
\hline & $\begin{array}{l}\text { screen printing and gra } \\
\text { arts }\end{array}$ & $\mathrm{c} 3.500$ & 7.912 & 1.000 & -21.49 & 28.49 \\
\hline & diploma in electrician & -27.000 & 9.135 & .086 & -55.86 & 1.86 \\
\hline \multirow[t]{8}{*}{ diploma in plumbing } & DAE mechanical & .015 & 7.601 & 1.000 & -23.99 & 24.03 \\
\hline & diploma in beautician & -13.531 & 6.994 & .591 & -35.62 & 8.56 \\
\hline & dress making & 9.233 & 8.747 & .979 & -18.39 & 36.86 \\
\hline & computer operator & -4.523 & 6.861 & .999 & -26.20 & 17.15 \\
\hline & auto mechanic & 3.900 & 12.085 & 1.000 & -34.27 & 42.07 \\
\hline & ac/ refrigeration repair & -7.092 & 5.098 & .899 & -23.19 & 9.01 \\
\hline & $\begin{array}{l}\text { screen printing and gra } \\
\text { arts }\end{array}$ & c3.485 & 6.076 & 1.000 & -15.71 & 22.68 \\
\hline & diploma in electrician & $-27.015^{*}$ & 7.601 & .015 & -51.03 & -3.01 \\
\hline \multirow[t]{8}{*}{ DAE mechanical } & diploma in plumbing & -.015 & 7.601 & 1.000 & -24.03 & 23.99 \\
\hline & diploma in beautician & -13.546 & 4.821 & .123 & -28.78 & 1.68 \\
\hline & dress making & 9.218 & 7.129 & .932 & -13.30 & 31.74 \\
\hline & computer operator & -4.538 & 4.626 & .987 & -19.15 & 10.07 \\
\hline & auto mechanic & 3.885 & 10.971 & 1.000 & -30.77 & 38.54 \\
\hline & $\mathrm{ac} /$ refrigeration repair & 6.455 & 4.139 & .824 & -6.62 & 19.53 \\
\hline & $\begin{array}{l}\text { screen printing and gra } \\
\text { arts }\end{array}$ & $\mathrm{c} 17.031^{*}$ & 5.297 & .043 & .30 & 33.76 \\
\hline & diploma in electrician & -13.469 & 6.994 & .598 & -35.56 & 8.62 \\
\hline \multirow[t]{8}{*}{ diploma in beautician } & diploma in plumbing & 13.531 & 6.994 & .591 & -8.56 & 35.62 \\
\hline & DAE mechanical & 13.546 & 4.821 & .123 & -1.68 & 28.78 \\
\hline & dress making & $22.764^{*}$ & 6.478 & .017 & 2.30 & 43.23 \\
\hline & computer operator & 9.008 & 3.542 & .222 & -2.18 & 20.20 \\
\hline & auto mechanic & 17.431 & 10.560 & .775 & -15.93 & 50.79 \\
\hline & ac/ refrigeration repair & -16.310 & 6.686 & .273 & -37.43 & 4.81 \\
\hline & $\begin{array}{l}\text { screen printing and gra } \\
\text { arts }\end{array}$ & $c-5.733$ & 7.459 & .997 & -29.29 & 17.83 \\
\hline & diploma in electrician & $-36.233^{*}$ & 8.747 & .002 & -63.86 & -8.61 \\
\hline \multirow[t]{5}{*}{ dress making } & diploma in plumbing & -9.233 & 8.747 & .979 & -36.86 & 18.39 \\
\hline & DAE mechanical & -9.218 & 7.129 & .932 & -31.74 & 13.30 \\
\hline & diploma in beautician & $-22.764^{*}$ & 6.478 & .017 & -43.23 & -2.30 \\
\hline & computer operator & -13.756 & 6.334 & .431 & -33.76 & 6.25 \\
\hline & auto mechanic & -5.333 & 11.794 & 1.000 & -42.59 & 31.92 \\
\hline computer operator & $\mathrm{ac} /$ refrigeration repair & -2.553 & 3.910 & .999 & -14.90 & 9.80 \\
\hline
\end{tabular}




\begin{tabular}{|c|c|c|c|c|c|c|}
\hline & $\begin{array}{l}\text { screen printing and } \mathrm{g} \\
\text { arts }\end{array}$ & c8.023 & 5.120 & .821 & -8.15 & 24.20 \\
\hline & diploma in electrician & $-22.477^{*}$ & 6.861 & .036 & -44.15 & -.80 \\
\hline & diploma in plumbing & 4.523 & 6.861 & .999 & -17.15 & 26.20 \\
\hline & DAE mechanical & 4.538 & 4.626 & .987 & -10.07 & 19.15 \\
\hline & diploma in beautician & -9.008 & 3.542 & .222 & -20.20 & 2.18 \\
\hline & dress making & 13.756 & 6.334 & .431 & -6.25 & 33.76 \\
\hline & auto mechanic & 8.423 & 10.472 & .997 & -24.66 & 41.50 \\
\hline & $\mathrm{ac} /$ refrigeration repair & -10.976 & 10.689 & .983 & -44.74 & 22.79 \\
\hline & $\begin{array}{l}\text { screen printing and } g \\
\text { arts }\end{array}$ & c-. 400 & 11.189 & 1.000 & -35.74 & 34.94 \\
\hline & diploma in electrician & -30.900 & 12.085 & .216 & -69.07 & 7.27 \\
\hline auto mechanic & diploma in plumbing & -3.900 & 12.085 & 1.000 & -42.07 & 34.27 \\
\hline & DAE mechanical & -3.885 & 10.971 & 1.000 & -38.54 & 30.77 \\
\hline & diploma in beautician & -17.431 & 10.560 & .775 & -50.79 & 15.93 \\
\hline & dress making & 5.333 & 11.794 & 1.000 & -31.92 & 42.59 \\
\hline & computer operator & -8.423 & 10.472 & .997 & -41.50 & 24.66 \\
\hline
\end{tabular}

Table 10 shows the result of post hoc analysis of ANOVA to identify teaching strategies of teachers of TVET institutions on the basis of their professional qualification showing $F(8,121)=4.251, p=.000$. Table values show that, teachers' responses vary about their teaching strategies on the basis of their professional qualification in teaching different courses to students. It is apparent that responses of teachers who have diploma in Ac/ refrigeration repair had significant difference with the responses of those who have diploma in electrician. Moreover, the teachers having the diploma in screen printing and graphic arts had a significant difference with the responses of those who have diploma in beautician. It is also evident from the table values that teachers having the diploma in electrician had significant difference with the responses of those who have diploma in mechanical, dress making and computer operator. DAE mechanical diploma holder had a significant difference with the responses of teachers having diploma in electrical and screen printing and graphic arts. Teachers having diploma in beautician had a significant difference with the responses of teachers having diploma in dress making. The table values also shows that the teachers having diploma in dress making and computer operator had a significant difference with the responses of teachers having diploma in electrician and beautician, while the rest of the teachers had no significant difference in their responses related to their teaching strategies.

Table 11:

ANOVA for differences in mean scores in teaching strategies of teachers on the basis of trainings

\begin{tabular}{|c|c|c|c|c|c|}
\hline & $\begin{array}{l}\text { Sum } \\
\text { Squares }\end{array}$ & $D f$ & Mean Square & $F$ & Sig. \\
\hline Between Groups & 3510.383 & 6 & 585.064 & 2.496 & .026 \\
\hline Within Groups & 28830.417 & 123 & 234.394 & & \\
\hline Total & 32340.800 & 129 & & & \\
\hline
\end{tabular}

Table 11 shows that there was statistically significant difference among the teaching strategies of teachers of TVET institutions on the basis of their trainings: $F(6,123)=2.496, p=.026$. It means that teachers' teaching strategies were different on the basis of their trainings in teaching different courses to students.

Table 12:

Post Hoc Comparison of teachers' teaching strategies on the basis of training

\begin{tabular}{|c|c|c|c|c|c|c|}
\hline \multirow[t]{2}{*}{ (I) training courses } & \multirow[t]{2}{*}{$(\mathrm{J})$ training courses } & \multirow{2}{*}{$\begin{array}{l}\text { Mean } \\
(\mathrm{I}-\mathrm{J})\end{array}$} & \multirow[t]{2}{*}{ DifferenceStd. Error } & \multirow[t]{2}{*}{ Sig. } & \multicolumn{2}{|c|}{ 95\% Confidence Interval } \\
\hline & & & & & Lower Bound & Upper Bound \\
\hline \multirow{2}{*}{ 1-5 workshops } & 6-10 workshops & $7.425^{*}$ & 3.006 & .039 & .30 & 14.55 \\
\hline & 11-15 workshops & 6.507 & 3.924 & .225 & -2.80 & 15.81 \\
\hline 6-10 workshops & 11-15 workshops & -.918 & 4.079 & .972 & -10.59 & 8.76 \\
\hline 11-15 workshops & 1-5 workshops & -6.507 & 3.924 & .225 & -15.81 & 2.80 \\
\hline
\end{tabular}

Table 12 shows the result of post hoc analysis of ANOVA to identify teaching strategies of teachers of TVET institutions on the basis of their trainings showing $F(6,123)=2.496, p=.026$. Table values show 
that teachers' responses vary about their teaching strategies on the basis of their nature of training in teaching different courses to students. It is apparent that responses of teachers who have attended 1-5 workshops had significant difference with the opinion of those attended 6-10 workshops. However, teachers attended 11-15 workshops were of the same opinion as teachers attended less workshops.

Table 13:

ANOVA for differences in mean scores among teaching strategies of teachers on the basis of experience

\begin{tabular}{llllll}
\hline & Sum of Squares & $D f$ & Mean Square & $F$ & Sig. \\
\hline Between Groups & 1811.701 & 4 & 452.925 & 1.854 & .123 \\
Within Groups & 30529.099 & 125 & 244.233 & & \\
Total & 32340.800 & 129 & & & \\
\hline
\end{tabular}

Table 13 shows that there was no statistically significant difference among the teaching strategies of teachers of TVET institutions on the basis of their age: $F(4,125)=1.854, p=123$. It means that teachers' teaching strategies were not different on the basis of their experience in teaching different courses to students.

Table 14:

ANOVA for differences in mean scores among teaching strategies of teachers on the basis of zones

\begin{tabular}{llllll}
\hline & Sum of Squares & $D f$ & Mean Square & $F$ & Sig. \\
\hline Between Groups & 3508.764 & 3 & 1169.588 & 5.111 & .002 \\
Within Groups & 28832.036 & 126 & 228.826 & & \\
Total & 32340.800 & 129 & & & \\
\hline
\end{tabular}

Table 14 shows that there was statistically significant difference among the teaching strategies of teachers of TVET institutions on the basis of their zones: $F(3,126)=5.111, p=.002$. It means that teachers' teaching strategies were significantly different on the basis of zones in teaching different courses to students.

Table 15:

Post Hoc Comparison of teachers' teaching strategies on the basis of zones

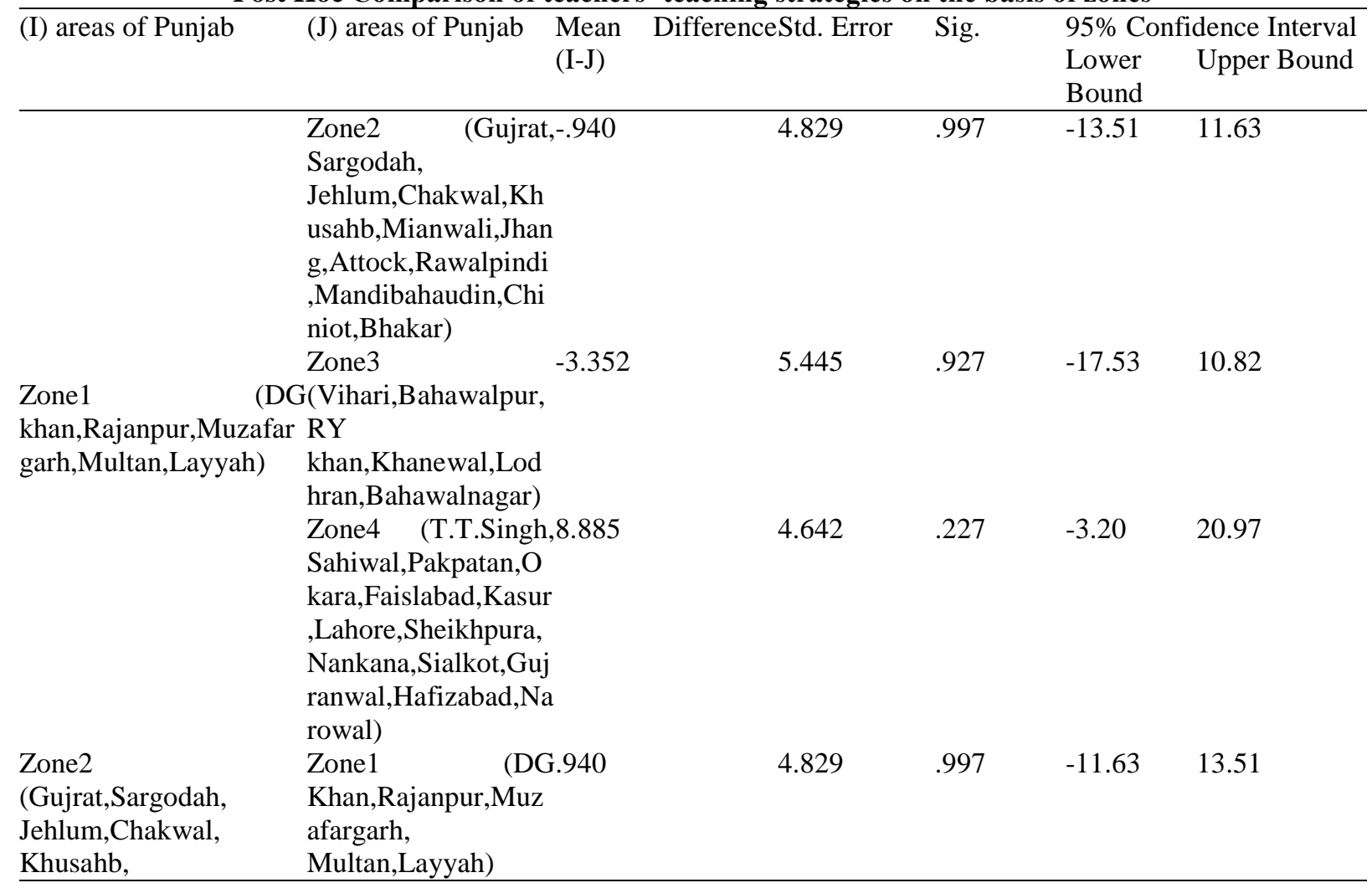




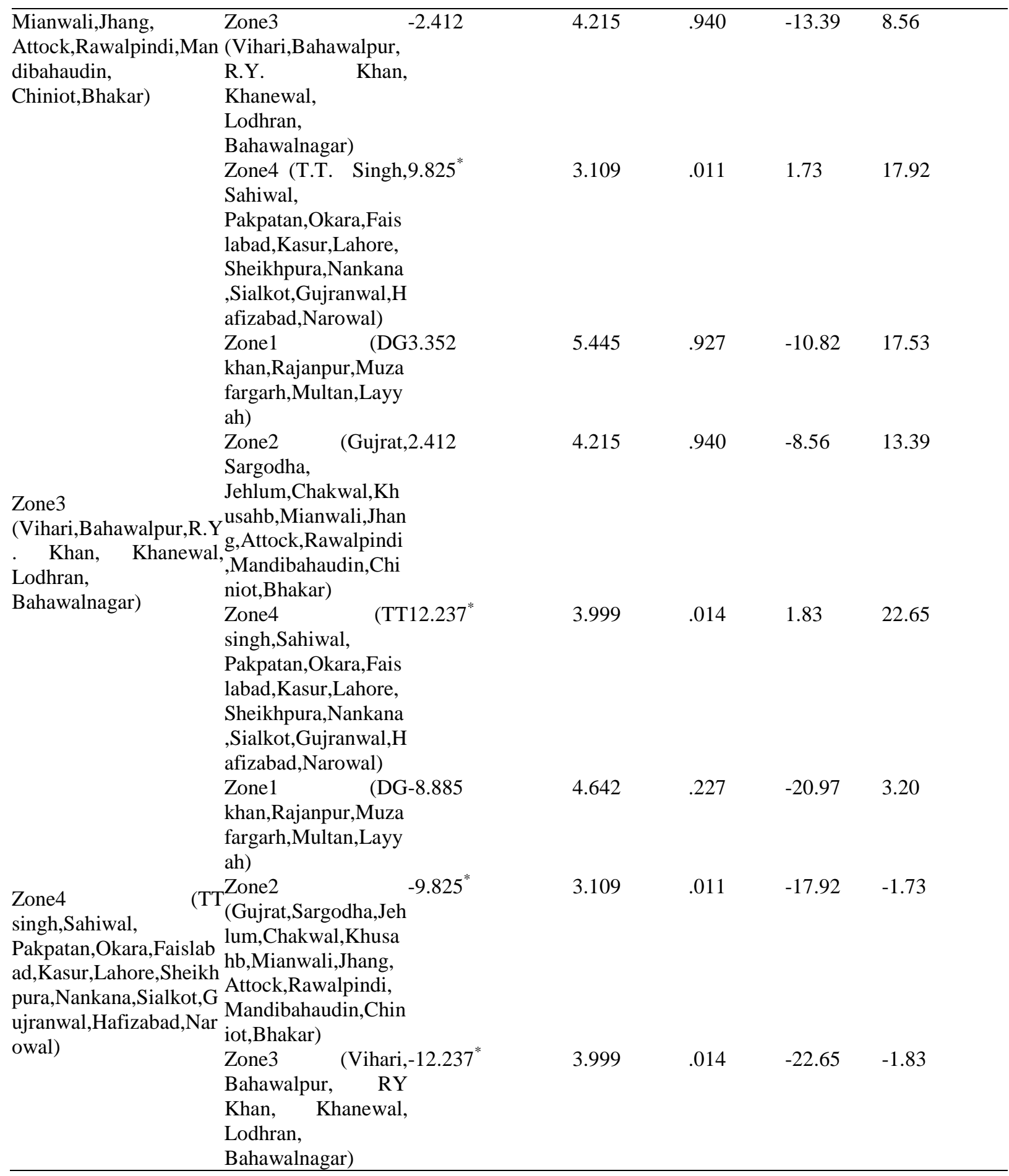

Table 15 shows the result of post hoc analysis of $A N O V A$ to identify teaching strategies of teachers of TVET institutions on the basis of the zones showing $F(3,126)=5.111, p=.002$. Table values show that, teachers' responses vary about their teaching strategies on the basis of their zones in teaching different courses to students. It is apparent that responses of teachers from zone 3 had significant difference $(\mathrm{p}=.014)$ with the responses of those teachers who are from zone 4. Moreover, the teachers from zone 4 also had a significant difference with responses of teachers from zone 2 and zone 3 ( $p=0.01$ and $p=$ $.001)$.

Table 16:

Independent sample t-test for comparison of teachers' responses on teaching strategies on the basis of gender

$\begin{array}{lllllll}\text { Variables } & \text { Gender } & N & \begin{array}{l}\text { Mean } \\ \text { Scores }\end{array} & D f & t \text {-value } & \text { Sig. }\end{array}$




\begin{tabular}{lccccc}
\hline Male & 69 & 177.57 & 128 & -2.860 & .005 \\
Female & 61 & 185.31 & & & \\
\hline
\end{tabular}

Table 16 indicates that an independent sample $t$-test was conducted using Leven's test of equality of variance to compare the opinion of teachers about the teaching strategies for TVET students on the basis of their gender. There was significant difference in the mean scores of male and female teachers about their teaching strategies. The magnitude of difference in the means also existed. It means that the male and female teachers were using different teaching strategies.

\section{Discussion}

On the basis of findings, it is indicated that vocational graduates are having problem in implementation of their learning at their workplaces as there is no appropriate equipment, materials and resources available to TVET teachers. In addition, instructors do not get the chance to attend training workshops every year but they tried their level best to improve the academics, technical and vocational skills of their students by using different teaching strategies.

The TVET infrastructure, the capacity and quality training to teaching staff is in need of up-gradation in existing vocational training institutions in Punjab. It is also noteworthy that a significant difference has been found among the teaching strategies of TVET teachers on the basis of their trainings and professional qualification. It was examined that teachers having more trainings and professional qualification in their related trade were using better and variant teaching strategies. It encourages the concept of encouraging teachers with more in-service academic and professional trainings.

\section{Recommendations}

The quality of TVET programs should be improved. This can be attained through providing appropriate facilities, equipment, useable tools, and by providing sufficient trainings to TVET persons. There should be suitable provision of teaching materials. Provision of in-service training for TVET personnel. Scholarships/grants should be provided to TVET teachers/ instructors. The limited number of students should be kept in one section to sustain quality of education and facilitate TVET teachers during execution of their duties. There should be proper monitoring and scrutiny of the implementation of TVET programs by government.

\section{References}

Bhurtel, A. (2015). Technical and Vocational Education and Training in Workforce Development. Journal of Training and Development, 1(1), 77-84. https://doi.org/10.3126/jtd.v1i0.13094

Clayton, B. \& Harris, R.(2018). Recent reforms in vocational education and training. International Journal of Training Research, 16 (2), 99-102. $\quad$ DOI: 10.1080/14480220.2018.1501913

Council for Technical Education and Vocational Training. (2012). A Profile of Technical and Vocational Education Providers. Retrieved from https://en.wikipedia.org/wiki/TVET_(Technical_and_Vocational_Education_and_Training)

Finnamore, E. (2020). Advantages of vocational training. Retrieved from https:/allaboutschoolleavers.co.uk/teachers/colleges/advantages-of-vocational-training on 15 August 2020.

Government of Pakistan (1947). Proceedings of the Pakistan Educational Conference held at Karachi from 27th November to 1st December 1947. Ministry of the Interior (Education Division): Pakistan.

Government of Pakistan (1959). Report of the Commission on National Education 1959. Government of Pakistan Press: Pakistan.

Government of Pakistan (1972). The Education Policy 1972-1980. Ministry of Education, Islamabad: 
Pakistan.

Government of Pakistan (1998). National Education Policy 1998-2010. Ministry of Education, Islamabad: Pakistan.

Government of Pakistan (2009). National Education Policy 2009. Ministry of Education, Islamabad: Pakistan.

International Labor organization. (2021). World Employment and Social Outlook - Trends. Retrieved from https://www.ilo.org/global/research/global-reports/weso/trends2021/lang--en/index.htm

Kayode, A., \& Akanani, A.(2016). Shortage of teaching personnel for technical and vocational education (Tve) in Oyo State: Issues, Challenges and the way forward international .Journal of Business and Management Invention ,5(10), 10-13.

Ministry of Federal Education and Professional Training. (2018). Government Of Punjab MFEPT programme. Retrieved from http://www.mofept.gov.pk/

Offei-Ansah, C. \& Amu, M.(2011).Linking tertiary institutions to industries: Evidence from the vocational and technical education department of the university of Cape Coast. International Journal of Vocational and Technical Education, 2 (5), 53-60.

Pioneer State High School (2020). Vocational Education and Training in schools. Retrieved from https://pioneershs.eq.edu.au/curriculum/vocational-education

Quisumbing, L. R. (2013). Education for the world of work and citizenship: Towards sustainable future societies. International Experts Meeting (Final Report) Bonn, Germany 25-28 October 2013.

Shakir, R, A.(2020). Need for robust TVET sector. Retrieved from https://tribune.com.pk/story/2202026/need-robust-tvet-sector

Shrestha, P, B. (2016). Vocational education and training graduates: Challenges in practical skills to the job market. International Journal of Management and Social Sciences 3(3),141-145.

Tafida, S. K, Clement C. K \& Raihan (2015). Strategies for retaining highly qualified and experienced technical teachers in teaching profession in Katsina State, Nigeria. International Journal of Asian Science. 5 (8), Pg 461- 468.

(UNESCO, 2010). Improving the participation of female students in tvet programmes formerly dominated by males. from https://unevoc.unesco.org/fileadmin/user_upload/docs/CS3_Philippines_Women.pdf 